\title{
A Novel Antigonadotropic Role of Thyroid Stimulating Hormone on Leydig Cell-Derived Mouse Leydig Tumor Cells-1 Line
}

\author{
${ }^{1}$ Department of Reproductive Biology, All India Institute of Medical \\ Sciences, New Delhi, India \\ 2Section on Endocrinology and Genetics, National Institute of Child \\ Health and Human Development, National Institutes of Health, \\ Bethesda, Maryland, United States
}

Bodhana Dhole ${ }^{1}$ Surabhi Gupta ${ }^{1}$ Skand Shekhar ${ }^{2}$ Anand Kumar ${ }^{1, *}$

\begin{abstract}
Address for correspondence Skand Shekhar, MD, Section on Endocrinology and Genetics, National Institute of Child Health and Human Development, National Institutes of Health, Bethesda, MD 20892, United States (e-mail: skand.shekhar@nih.gov).
\end{abstract}

Ann Natl Acad Med Sci (India) 2020;56:30-37

\author{
Abstract \\ Keywords \\ - Leydig cells \\ - steroidogenesisthyroid \\ stimulating hormone \\ receptor \\ - thyroid stimulating \\ hormone
}

Subclinical hypothyroid men characterized by a rise in only thyroid stimulating hormone (TSH) levels, and normal thyroid hormone levels showed a fall in their serum progesterone and testosterone levels. This suggested a role of TSH in regulating Leydig cell steroidogenesis. Therefore, we investigated the direct role of TSH on steroid production and secretion using a mouse Leydig tumor cell line- 1 (MLTC-1). MLTC- 1 cells were treated with different doses of TSH isolated from porcine pituitary as well as recombinant TSH. Steroid secretion was measured by radioimmunoassay (RIA). The mRNA levels of steroidogenic enzymes were quantitated by real-time polymerase chain reaction (RT-PCR), whereas the corresponding protein levels were determined by western blot. In MLTC-1 cells, pituitary TSH as well as recombinant TSH inhibited progesterone and testosterone secretion in a dose-dependent manner. The inhibitory action of TSH on steroid secretion was unique and not mimicked by other anterior pituitary hormones including follicle stimulating hormone and adrenocorticotropic hormone. Recombinant TSH showed no effect on steroidogenic acute regulatory protein and CYP11A1, the enzymes catalyzing the nonsteroidogenic and steroidogenic rate-limiting steps of steroid synthesis, respectively. Recombinant TSH was shown to inhibit steroidogenesis in MLTC- 1 cells by inhibiting the 3- $\beta$ hydroxy steroid dehydrogenase mRNA and protein levels, the enzyme that catalyzes the conversion of pregnenolone to progesterone. This inhibitory effect of TSH is probably direct as both mRNA and protein of the TSH receptor were shown to be present in the MLTC- 1 cells.

\section{Introduction}

The thyroid hormone 3, 5, 3'-L-triiodothyronine $\left(\mathrm{T}_{3}\right)$ was shown to increase the basal and 3', 5' cyclic adenosine monophosphate (CAMP)-stimulated steroid production in primary Leydig cells and their derived lines. ${ }^{1-3}$ Overt hypothyroid men showed a significant reduction in their serum progesterone and testosterone levels. ${ }^{4}$ This reduction in serum steroid levels could be due to reduced thyroid hormone levels or increased thyroid stimulating hormone (TSH) levels or both. Although animal studies have consistently showed the direct effects of $T_{3}$ on Leydig cell function in the form of cell proliferation and steroidogenesis; however, the exact effects and mechanisms of action remain controversial.5, Inconsistencies in the findings of existing literature about the impact of hypothyroidism on testosterone and gonadotropin production raise questions about the role of TSH in vivo.7,8 Studies in subclinical hypothyroid men,

\section{${ }^{*}$ Retired}

DOI https://doi.org/

10.1055/s-0040-1709091

ISSN 0379-038X.
C2020 National Academy of

Medical Sciences (India)
License terms

() (1) $\ominus \circledast$ 
characterized by a rise in only TSH levels with normal thyroid hormone levels, also showed a similar reduction in serum progesterone and testosterone levels. ${ }^{9}$ As only TSH was raised in these subclinical hypothyroid men, this furthers the suggestion that a direct inhibitory action of TSH occurs on steroid production. Interestingly, studies have demonstrated the presence of TRH receptors on Leydig cells, which is unique to them among all testicular cell types. ${ }^{10}$ This also raises the possibility of other thyroid function modulating hormones such as TSH, acting on Leydig cells through their receptors. To date, no studies have been conducted to see the direct modulation of steroid production and secretion by TSH in Leydig cells.

Therefore, we investigated the role of TSH on steroid production and secretion using a mouse Leydig tumor cell line-1 (MLTC-1). We also investigated the effect of TSH on steroidogenic enzymes to dissect out the molecular mechanism(s) used by TSH for regulating steroid secretion.

\section{Materials and Methods}

\section{Ethics Clearance}

The study protocol was approved by the Institute Ethics committee of All India Institute of Medical Sciences.

\section{Hormones and Chemicals}

Pituitary-derived TSH, luteinizing hormone (LH), follicle-stimulating hormone (FSH), and adrenocorticotropic hormone (ACTH) were purchased from Sigma-Aldrich (St. Louis, Missouri, United States). Recombinant TSH was purchased from R\&D Systems (Minneapolis, Minnesota, United States). Tritium-labeled radioactive progesterone and testosterone were purchased from Perkin Elmer (Waltham, Massachusetts, United States). Both the mouse monoclonal testosterone antibody (clone 4E1G2) and rabbit polyclonal progesterone antibody were purchased from Bio-Rad (Hercules, California, United States). Primers were purchased from Sigma-Aldrich. Rabbit antisteroidogenic acute regulatory protein (StAR) antibody and rabbit anti-CYP11A1 antibody were purchased from Cell Signaling Technologies (Boston, Massachusetts, United States). Rabbit anti-3ß-hydroxy steroid dehydrogenase-1 (3ß-HSD) antibody and rabbit anti-TSH receptor antibody were purchased from Abcam (Cambridge, United Kingdom). Antirabbit HRP-labeled secondary antibody was purchased from Cell Signaling Technologies.

\section{Cell Culture}

MLTC- 1 cells were obtained from the American Type Culture Collection (Manassas, Virginia, United States). MLTC-1 cells express the human chorionic gonadotropin (hCG) receptor. They respond to $\mathrm{LH} / \mathrm{hCG}$ with stimulation of steroid production. ${ }^{11}$ The MLTC-1 cells were routinely maintained in Waymouth MB 752/1 medium (Sigma-Aldrich) supplemented with $10 \%$ heat-inactivated fetal bovine serum (Sigma-Aldrich, St. Louis, Missouri, United States) at $37^{\circ} \mathrm{C}$ in $5 \% \mathrm{CO}_{2}$ in a humidified incubator. The MLTC- 1 cells used for all the experiments had a passage number less than 30 .

\section{Cell Treatments}

MLTC- 1 cells were seeded at a density of $2 \times 10^{5}$ cells $/ \mathrm{mL} /$ well for measuring steroid secretion and at $1 \times 10^{6}$ cells/well for total RNA extraction and western blot assays. MLTC-1 cells were preincubated separately for 2 hours with different doses of pituitary or recombinant TSH, or FSH or ACTH in serum free media. Thereafter, the cells were incubated with $100 \mathrm{mIU} / \mathrm{mL} \mathrm{LH}$ or $1 \mathrm{mM}$ 8-Br-cAMP. The total period of incubation including the time of preincubation was 6 hours as MLTC- 1 cells begin proliferation by 9 hours. Viability of the cells after treatment were tested using [3-(4, 5-dimethylthiazol-2-yl)-2, 5-diphenyltetrazolium bromide] (MTT, SigmaAldrich, St. Louis, Missouri, United States).

\section{Steroid Production}

Steroid secretion was measured in cell supernatant by RIA according to the World Health Organization guidelines. Both the mouse monoclonal testosterone antibody (clone 4E1G2) and rabbit polyclonal progesterone antibody were used at a dilution of 1:500. The progesterone antibody used for RIA was highly specific and showed no crossreactivity for pregnenolone as well as for testosterone. However, the testosterone antibody also recognizes $5 \alpha$-dihydrotestosterone (DHT, 1\%) and androstenedione (1\%). The intraassay variation was less than $5 \%$, and the interassay variation was less than $10 \%$.

\section{RNA Extraction and Reverse Transcriptase Polymerase Chain Reaction}

Total RNA was extracted using Ribozol RNA extraction reagent (Amresco, Solon, Ohio, United States) as per manufacturer's instructions. Total RNA isolated from the cells was reverse transcribed using oligo dT primers and Revert Aid First Strand cDNA Synthesis Kit (Thermo Scientific, Waltham, Massachusetts, United States). The cDNA synthesized was amplified using gene-specific primers (Sigma-Aldrich, St. Louis, United States). The sequences of StAR primers were forward 5' GACCTTGAAAGGCTCAGGAAGAAC 3' and reverse 5' TAGCTGAAGATGGACAGACTTGC3'. ${ }^{1}$ The sequences ofCYP11A1 primers were forward 5' CAACATCACAGAGATGCTGGCAGG3' and reverse $5^{\prime}$ CTCAGGCATCAGGATGAGGTTGAA $3^{\prime} .^{\prime 2}$ The sequences of $3 \beta$-HSD-I primers were forward $5^{\prime}$ GACAGGAGCAGGAGGGTTTGTGG $3^{\prime}$ and reverse $5^{\prime}$ CTCCTTCTAACATTGTCACCTTGGCCT $33^{\prime} .^{13}$ The sequences of TSH receptor (TSHR) primers were forward 5' TTC CAG CCG CTG CAG AGT TGC3' and reverse 5' GAG TGT GCG TCT CCA CCC TG $3^{\prime} .^{\prime 4}$ The sequences of GAPDH primers were forward 5' ACGGGAAGCTTGTCATCAAT $3^{\prime}$ and reverse 5'TGGACTCCACGACGTCGTACTCA $33^{\prime} .^{15}$ The steroidogenic enzymes were amplified by quantitative RT-PCR. The PCR conditions used were initial denaturation at $95^{\circ} \mathrm{C}$ for 5 minutes, which followed by 40 cycles of $95^{\circ} \mathrm{C}$ for 20 seconds, $56^{\circ} \mathrm{C}$ for 20 seconds, and $72^{\circ} \mathrm{C}$ for 40 seconds. Ct values obtained during the RT-PCR reaction were used to calculate the relative mRNA expression using the formula: relative 
mRNA expression ${ }_{\text {StAR/CYP11A1/3 }} \beta_{-H S D}=2^{-\Delta \Delta \mathrm{Ct}}$, where $\Delta \mathrm{Ct}=\mathrm{Ct}_{\mathrm{StAR} /}$ ${ }_{\text {CYP11A1/3 }} \beta_{\text {-HSD- }} \mathrm{Ct}_{\text {GAPDH }}$ and $\Delta \Delta \mathrm{Ct}=\Delta \mathrm{Ct}_{\text {Basal }}-\Delta \mathrm{Ct}_{\text {Treated }}$. The TSHR gene was amplified by semiquantitative RT-PCR. The PCR conditions used were initial denaturation at $95^{\circ} \mathrm{C}$ for 3 minutes, which followed by 40 cycles of $95^{\circ} \mathrm{C}$ for 30 seconds, $60^{\circ} \mathrm{C}$ for 20 seconds, and $72^{\circ} \mathrm{C}$ for 45 seconds. The amplified products were size-fractionated in a $2 \%(\mathrm{w} / \mathrm{v})$ agarose gel and visualized by staining with ethidium bromide $(0.2 \mathrm{ng} / \mathrm{mL})$.

\section{Western Blot}

Total protein extracts were separated by sodium dodecyl sulfate/polyacrylamide gel electrophoresis (SDS/PAGE) using $12 \%$ resolving gel. The protein bands in the gel were transferred onto a 0.45 - $\mu \mathrm{m}$ polyvinylidene fluoride membrane. Polyvinylidene fluoride membrane was blocked with $5 \%$ bovine serum albumin solution made in TBS-T $(0.1 \%$ Tween-20 in 1× TBS). The membrane was probed with rabbit anti-StAR antibody, rabbit anti-CYP11A1 antibody, rabbit anti-3 $\beta$-HSD antibody, rabbit anti-TSHR antibody, or rabbit anti- $\beta$-actin antibody. A 1:1,000 dilution was used for each of the primary antibody and incubated for overnight at $4{ }^{\circ} \mathrm{C}$. Antirabbit HRP-labeled secondary antibody at 1:3,000 dilution was used. Protein bands were visualized using ECL system (Merck Millipore, Billerica, United States). The density of the protein bands was measured using Image software developed at the National Institute of Health (Bethesda, Maryland, United States).

\section{Statistical Analysis}

All the treatments were performed in triplicates and at least three times. The data were pooled and analyzed using GraphPad Prism 4.0 software (GraphPad Prism Software Inc., San Diego, California, United States). The results were analyzed by Student's $t$-test. A $p$-value $<0.05$ was considered significant.

\section{Results}

\section{TSH Inhibits Steroid Secretion}

Initially, different doses of pituitary TSH ranging from 1 to $100 \mathrm{mIU} / \mathrm{mL}$ were tested for their effect on steroid secretion by MLTC- 1 cells. The minimum dose of $1 \mathrm{mIU} / \mathrm{mL}$ of TSH showed no significant effect on basal, LH or 8-Br-cAMPstimulated progesterone and testosterone secretion. However, the higher doses of TSH significantly inhibited both progesterone and testosterone secretion in a dose dependent manner (-Fig. 1A, B). About $100 \mathrm{mIU} / \mathrm{mL}$ of TSH inhibited basal progesterone and testosterone secretion by 37 and 39\%, respectively (-Fig. 1A, B). $100 \mathrm{mIU} / \mathrm{ml}$ of TSH also inhibited LH and 8-Br-cAMP-stimulated progesterone secretion by 35 and $25 \%$, respectively. About $100 \mathrm{mIU} / \mathrm{mL}$ of TSH inhibited $\mathrm{LH}$ and 8-Br-cAMP-stimulated testosterone secretion by 42 and $27 \%$, respectively (-Fig. $\mathbf{1 A}$, B).

\section{Effect of TSH on Steroid Secretion is Specific}

To rule out the possibility that the inhibitory effect of TSH on steroid secretion is nonspecific in nature, we used two other pituitary-derived hormones: FSH and ACTH. However, both FSH and ACTH showed no significant effect on basal, LH or 8-Br-cAMP-stimulated progesterone and testosterone secretion (-Fig. 2A-D). This suggested that steroid secretion is specifically inhibited by TSH.

To further confirm that the inhibitory effect of TSH was not due to any other contaminant present in the pituitary extract, we used recombinant TSH (rTSH). The minimum dose of $0.15 \mathrm{ng} / \mathrm{mL}$ of rTSH showed no significant effect on basal or 8-Br-cAMP-stimulated progesterone and testosterone secretion. However, both the higher doses of rTSH significantly inhibited both progesterone and testosterone secretion in a dose-dependent manner (-Fig. 3A, B). While $1.5 \mathrm{ng} / \mathrm{mL}$ of rTSH inhibited basal progesterone and testosterone secretion by 32 and 31\%, $15 \mathrm{ng} / \mathrm{mL}$ of rTSH inhibited those by 61 and 45\%, respectively (-Fig. 3A, B). The inhibitory effect of rTSH on 8-Br-cAMP-stimulated progesterone and testosterone secretion was even more pronounced. Maximal inhibition was observed with $15 \mathrm{ng} / \mathrm{mL}$ of $\mathrm{rTSH}$ on 8-Br-cAMP-stimulated progesterone and testosterone secretion by 48 and $49 \%$, respectively (-Fig. 3A, B).

\section{Effect of TSH on Expression of Steroidogenic Enzymes}

The molecular mechanism underlying the inhibition of steroid secretion by TSH was worked out by studying the expression of the steroidogenic enzymes after treatment with rTSH. Interestingly, rTSH showed no significant effect on StAR and CYP11A1 mRNA and protein levels in MLTC-1 cells (-Figs. 4A, B and 5A, B), but expression of 3 $\beta$-HSD was significantly reduced by both 1.5 and $15 \mathrm{ng} / \mathrm{mL}$ dose of rTSH (-Figs. 4C and 5C). Total $15 \mathrm{ng} / \mathrm{mL}$ of rTSH inhibited basal and 8 -Br-cAMP-stimulated 3ß-HSD1-I mRNA levels by 37 and $51 \%$, respectively ( - Fig. $4 \mathbf{C}$ ), while the protein levels were inhibited by 40 and 53\%, respectively (-Fig. 5C).

\section{TSHR is Expressed by Mouse Leydig Tumor Cell Line-1 Cells}

Next we investigated whether the action of TSH on MLTC-1 cells was mediated through its specific G-protein coupled plasma membrane receptor. We performed RT-PCR using specific primers for TSHR and western blot using anti-TSHR antibody to detect the presence of TSHR mRNA and protein in MLTC-1 cells. RNA or protein isolated from thyroid tissue was used as positive control while Vero cells, a monkey kidney derived cell line, were used as negative control. TSHR mRNA and the corresponding protein were identified in the MLTC-1 cells (-Fig. 6).

\section{Discussion}

Primary Leydig cells are available only in small numbers and are often contaminated with other cell types. Therefore, for the present investigation, we have used Leydig cell-derived cell line, MLTC- 1 .

In Leydig cell-derived MLTC-1 cell line, TSH isolated from porcine pituitary significantly decreased basal progesterone and testosterone secretion in a dose-dependent manner (-Fig. 1A, B). TSH also inhibited LH and 8-Br-cAMP-stimulated 
A
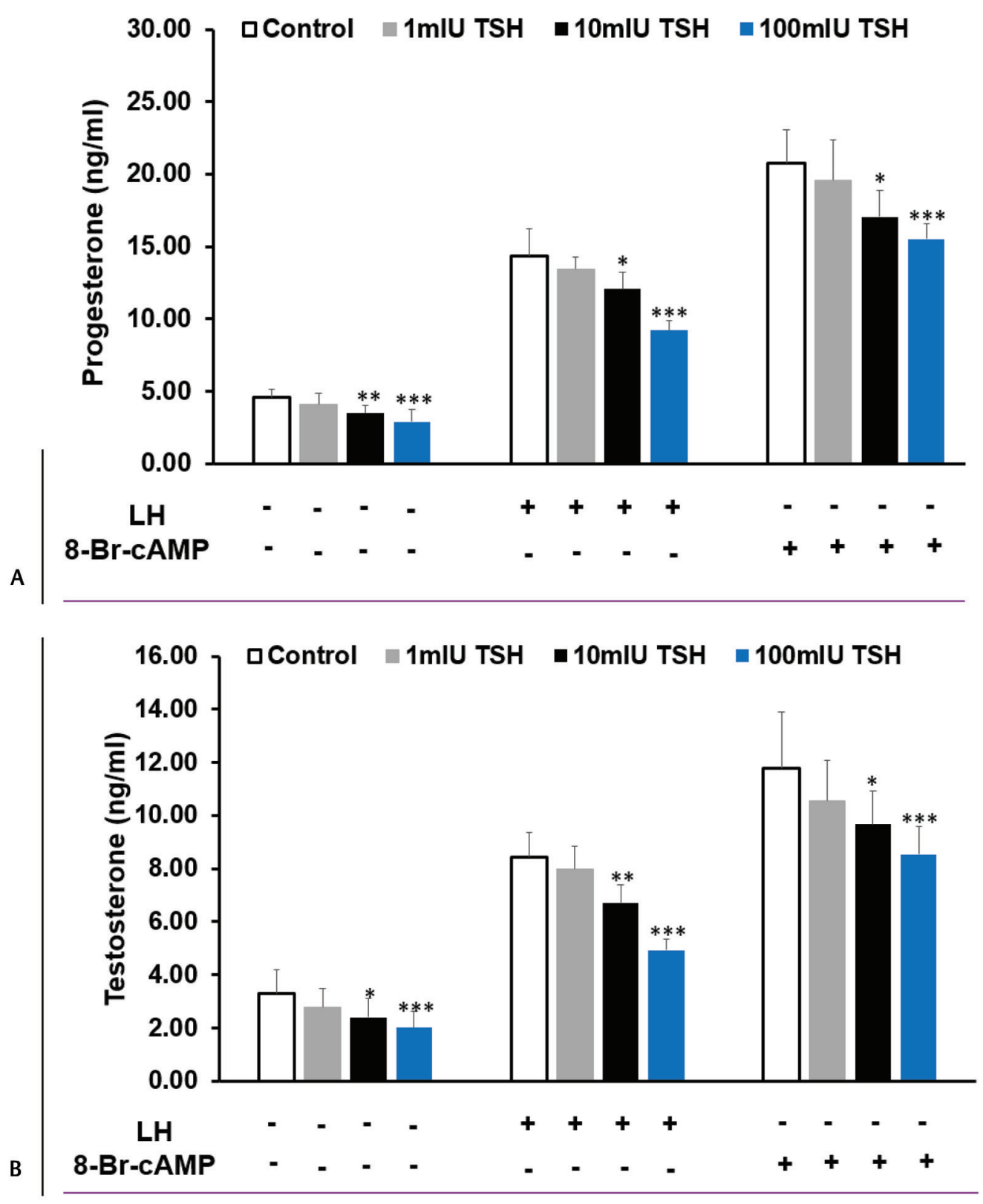

Fig. 1 Effect of pituitary TSH on (A) progesterone (B) testosterone secretion by mouse Leydig tumor cell line-1 cells under basal and treated conditions. Luteinizing hormone or 8-Br-cAMP was added after 2-hour preincubation with different doses of TSH. Bars represent mean \pm standard deviation of three experiments; each experiment was done at least in triplicates $(n=10) .{ }^{*}$ indicate $p<0.05 ;{ }^{* *}$ indicate $p<0.01$; and ***indicate $p<0.001$ in cells treated without and with TSH in the corresponding groups. TSH, thyroid stimulating hormone.

progesterone and testosterone secretion suggesting that the inhibitory effect of TSH on steroids is distal to adenylate cyclase enzyme effect. Similarly, in primary cultures of rat granulosa cells, TSH was shown to inhibit steroid secretion. ${ }^{16}$ This finding was also confirmed in monkey and human granulosa cells. ${ }^{17}$

To rule out if the inhibitory effect of TSH on steroid secretion is nonspecific in nature, we used FSH and ACTH. FSH is structurally related to TSH; both having a common $\alpha$ subunit. FSH is secreted by anterior pituitary gonadotrophs. The inhibitory action of TSH on steroid secretion was not mimicked by FSH (-Fig. 2A,B). ACTH, another protein secreted by the anterior pituitary, but structurally unrelated to TSH also showed no significant effect on basal or 8-Br-cAMP-stimulated steroid secretion ( - Fig. 2C,D). This suggests that the inhibitory effect of TSH on steroid secretion is unique and a specific property of the TSH hormone.

To work out the molecular mechanismof inhibition, we have used rTSH for further experiments. Pituitary preparations of TSH are mostly tainted with other contaminants. Therefore, to rule out the possibility that the inhibitory effect of TSH on steroids was not due to the contaminating molecules, we used 

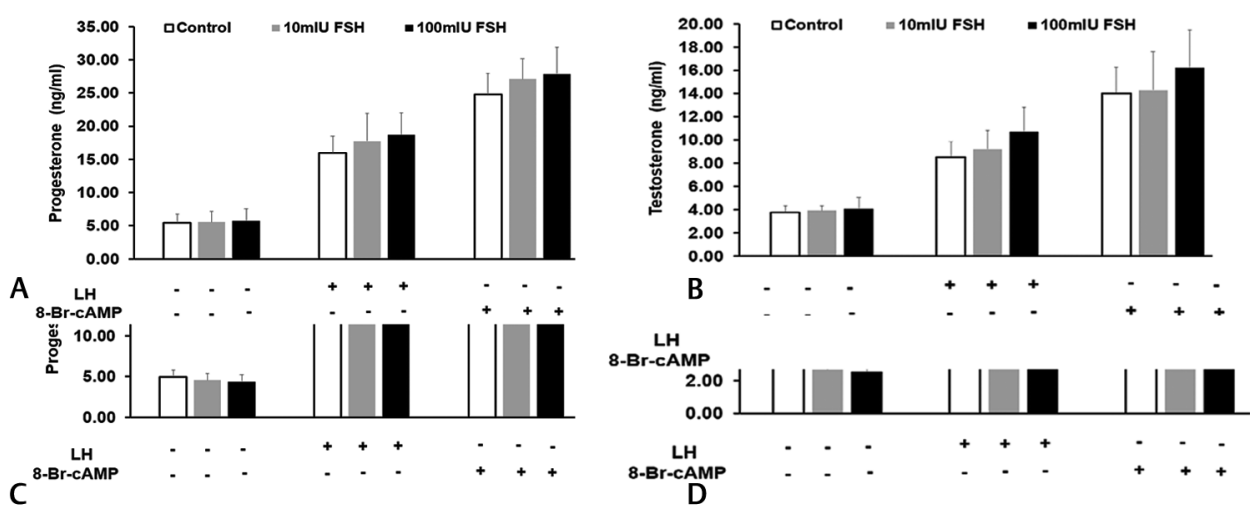

Fig. 2 Effect of pituitary FSH on (A) progesterone (B) testosterone secretion; effect of pituitary ACTH on (C) progesterone and (D) testosterone secretion by mouse Leydig tumor cell line-1 cells under basal and treated conditions. LH or 8-Br-cAMP were added after 2 hour preincubation with different doses of FSH or ACTH. Bars represent mean \pm standard deviation of three experiments; each experiment was done at least in triplicates $(n=10)$. ACTH, adrenocorticotropic hormone; FSH, follicle-stimulating hormone.

rTSH. The rTSH, too, significantly inhibited progesterone and testosterone secretion from MLTC-1 cells confirming a direct inhibitory effect of TSH on steroid production ( - Fig. 3A, B).

To investigate the inhibitory mechanism of TSH on steroid synthesis, we studied the effect of rTSH on various steroidogenic enzymes. StAR, a de novo-synthesized labile protein, catalyzes the intermitochondrial cholesterol transport. ${ }^{18-20}$ The cholesterol in the inner mitochondrial membrane is converted to pregnenolone with the help of CYP11A1 enzyme. StAR and CYP11A1 catalyze the nonsteroidogenic and steroidogenic rate-limiting steps of steroid synthesis, respectively. ${ }^{21,22}$ TSH showed no significant effect on StAR and CYP11A1 mRNA and protein levels in MLTC-1 cells (-Figs. $\mathbf{4}$ and $\mathbf{5}$ ). This suggests that TSH acts at a site distal to pregnenolone synthesis. However, as TSH inhibits progesterone secretion, therefore its site of action is proximal to progesterone synthesis.

In rodents, steroidogenesis is primarily through the $\Delta 4$ pathway where conversion of pregnenolone to progesterone is catalyzed by $3 \beta-H S D$ enzyme. ${ }^{23}$ In mouse, the $3 \beta-H S D 1$ isoform is primarily expressed in the gonads. ${ }^{24}$ Therefore, we studied the effect of rTSH on 33-HSD1 mRNA and protein levels. In MLTC-1 cells, TSH significantly inhibited basal and 8-Br-cAMP-treated 3 3 -HSD mRNA and protein levels (-Figs. 4 and 5 ). The inhibition of $3 \beta$-HSD by TSH in this study is similar to that observed in primary cultures of rat granulosa cells. ${ }^{16}$

Next we investigated whether the direct action of TSH on MLTC-1 cells was mediated through its specific G-protein coupled plasma membrane receptor. Till date, there is only

\section{$\square$ Control $\square 0.15 \mathrm{ng} / \mathrm{ml} \mathrm{rTSH} \square 1.5 \mathrm{ng} / \mathrm{ml} \mathrm{rTSH} \square 15 \mathrm{ng} / \mathrm{ml} \mathrm{rTSH}$}

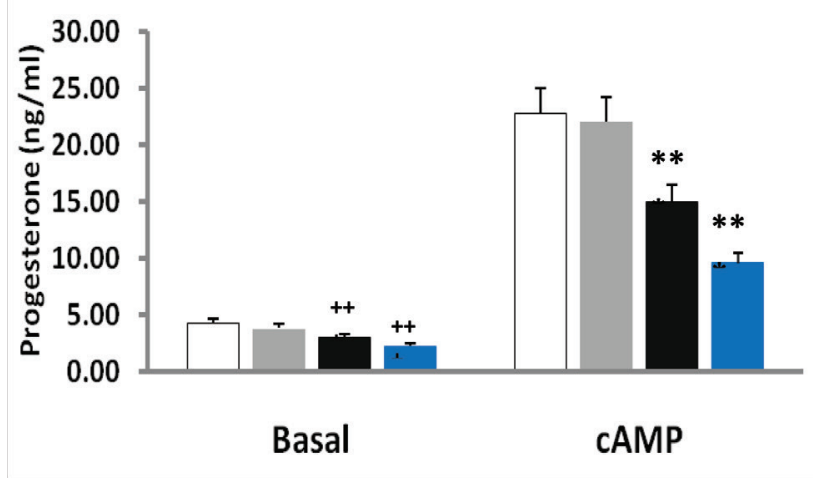

A $\square$ Control $\square 0.15 \mathrm{ng} / \mathrm{ml} \mathrm{rTSH} \square 1.5 \mathrm{ng} / \mathrm{ml} \mathrm{rTSH} \backsim 15 \mathrm{ng} / \mathrm{ml} \mathrm{rTSH}$

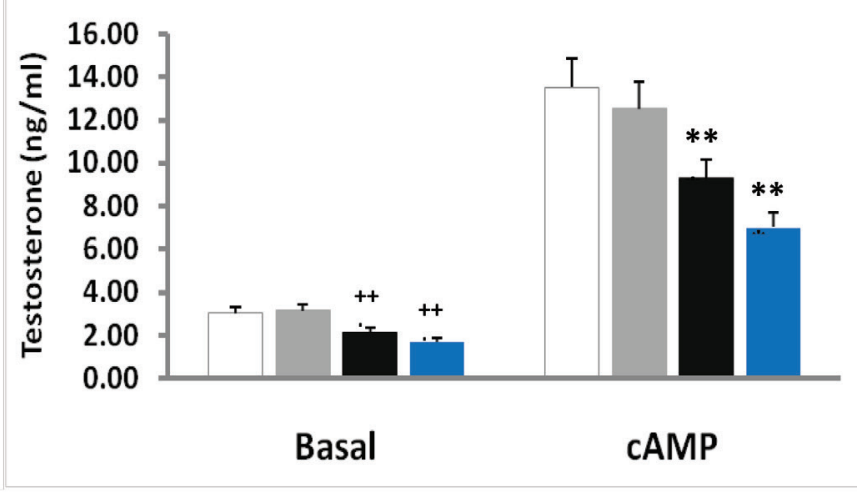

B

Fig. 3 Effect of recombinant TSH (rTSH) on (A) progesterone (B) testosterone secretion by mouse Leydig tumor cell line-1 cells under basal and treated conditions. 8-Br-cAMP was added after 2-hour preincubation with different doses of TSH. Bars represent mean \pm standard deviation of three experiments; each experiment was done at least in triplicates $(n=10) .{ }^{++}$indicate $p<0.001$ in cells treated without and with TSH in the basal group. ${ }^{* * *}$ indicate $p<0.001$ in cells treated without and with TSH in the 8-Br-cAMP treated group. TSH, thyroid stimulating hormone. 


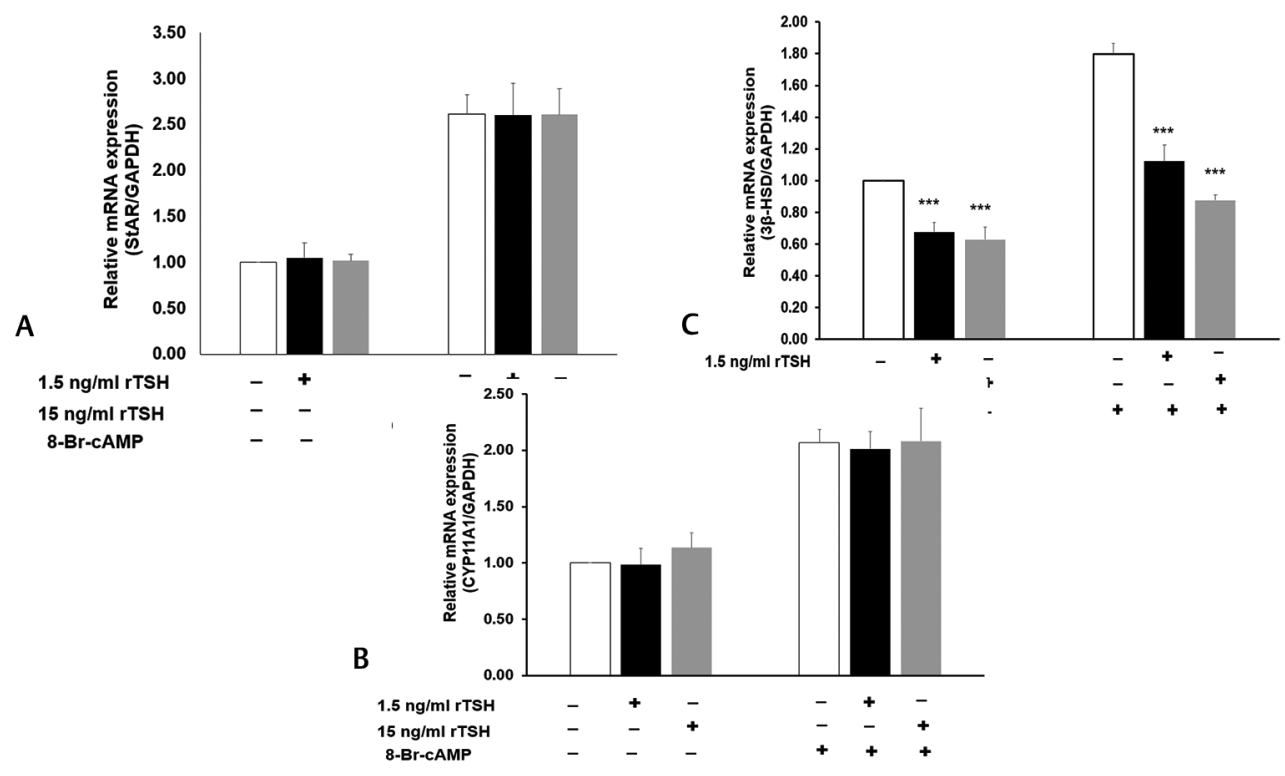

Fig. 4 Effect of rTSH on (A) StAR (B) CYP11A1 and (C) 3B-HSD mRNA levels by quantitative real time PCR after normalization with GAPDH. Bars represent mean \pm standard deviation of three experiments; each experiment was done in triplicates $(n=9)$. ${ }^{* * *}$ indicate $p<0.001$ in cells treated without and with TSH in the corresponding groups. rTSH, recombinant thyroid stimulating hormone;) StAR, steroidogenic acute regulatory protein.

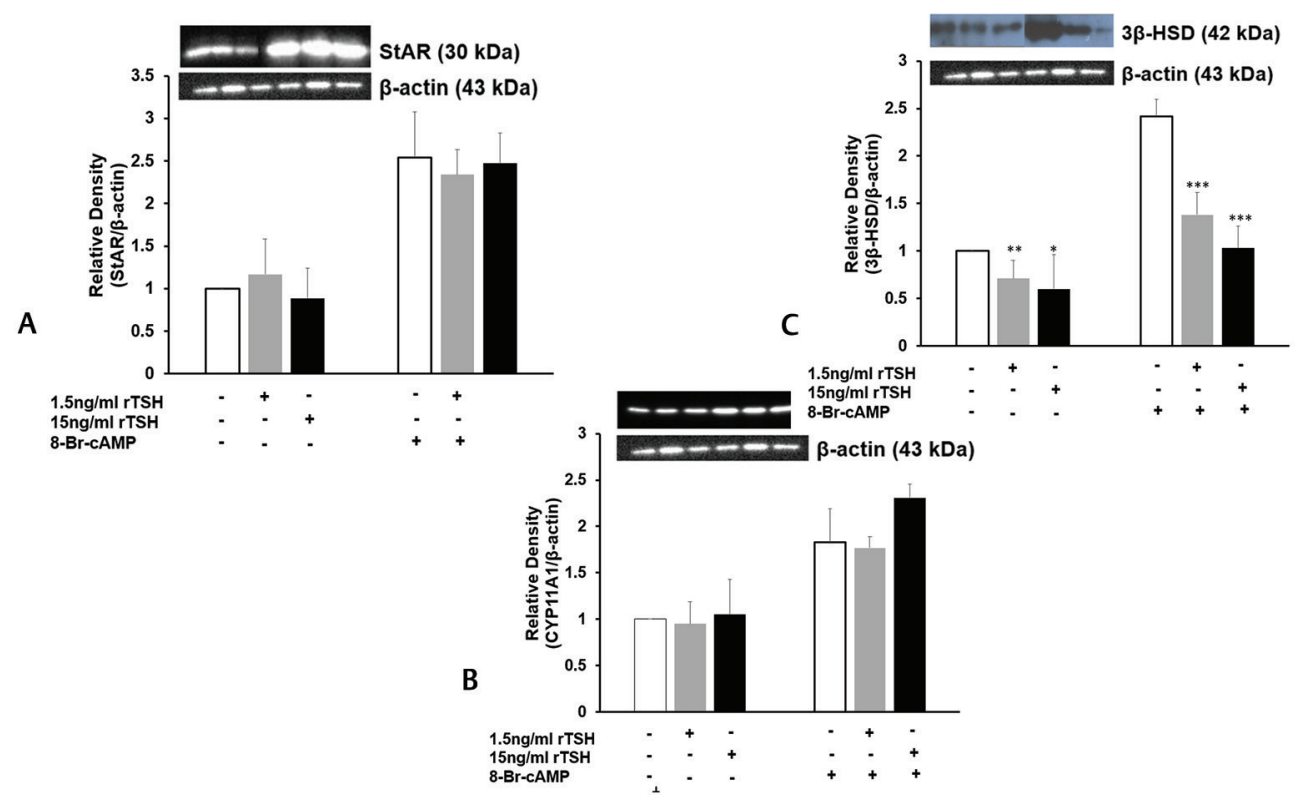

Fig. 5 Effect of rTSH on (A) StAR (B) CYP11A1 and (C) 33-HSD protein levels by Western blot after normalization with $\beta$-actin. Bars represent mean \pm standard deviation of densitometric measurements of Western blot bands. ${ }^{*}$ indicate $p<0.05 ;{ }^{* *}$ indicate $p<0.01 ;{ }^{* * *}$ indicate $p<0.001$ in cells treated without and with TSH in the corresponding groups. StAR, steroidogenic acute regulatory protein.

one additional report showing the presence of TSH receptors on Leydig cells that was reported after our findings were presented. ${ }^{25,26}$ However, TSH receptors have been identified on the granulosa cells of several species including rat and monkey. ${ }^{17,27}$ In MLTC-1 cells like that seen in thyroid tissue, both the TSHR and the corresponding protein were identified suggesting that the inhibitory action of TSH on steroidogenesis could be mediated through its receptor. TSHR was not identified in Vero cells, a monkey kidney derived line but has been identified in rat Leydig cells. ${ }^{25}$

However, in human thyroid tissue, when TSH binds to its receptor, it activates two G-proteins: $\mathrm{G}_{\mathrm{s}}$ and $\mathrm{G}_{\mathrm{q} / 11}{ }^{28}$. The active $\mathrm{G}_{\mathrm{s}}$ inducetheadenylylcyclase-cAMPpathway.Theactive $G_{\mathrm{q} / 11}$ activates the phospholipase C-IP3 (inositoltriphosphate)/diacyl 


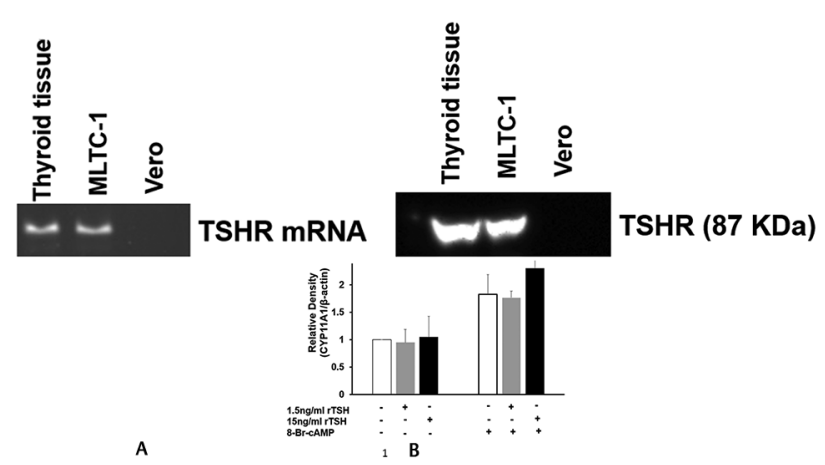

Fig. 6 Presence of (A) TSHR mRNA and (B) TSHR protein in thyroid tissue and mouse Leydig tumor cell line-1cells.

glycerol (DAG) pathway. DAG activates the protein kinase C (PKC). ${ }^{28,29}$ In Y1 adrenocortical cells, PKC was shown to inhibit basal steroidogenesis by inhibiting the mRNA expression of two steroidogenic enzymes: P450-11 $\beta$-hydroxylase and $3 \beta$-HSD. ${ }^{30}$ In hamster cell lines, PKC has also been shown to influence the genetic expression of CYP11B2. ${ }^{31}$ The signaling mechanism by which TSH inhibits the $3 \beta-H S D$ enzyme is yet to be determined in Leydig cells.

Our study is the first of its kind demonstrating a direct role of TSH on Leydig cell line and has demonstrated a molecular basis for its effects. We are also the first to demonstrate the presence of TSH receptors in Leydig cell line. There is a high probability of this physiology in human Leydig cells, but further studies are needed on primary human Leydig cell lines to redemonstrate these findings and establish the presence of this phenomenon in, as well as the TSH and these receptors in human Leydig cells.

\section{Note}

This study was previously presented as a poster presentation at the Endocrine Society meeting at Orlando, United States in April, 2017. ${ }^{26}$

\section{Funding \\ None.}

\section{Conflict of Interest}

None declared.

\section{References}

1 Manna PR, Kero J, Tena-Sempere M, Pakarinen P, Stocco DM, Huhtaniemi IT. Assessment of mechanisms of thyroid hormone action in mouse Leydig cells: regulation of the steroidogenic acute regulatory protein, steroidogenesis, and luteinizing hormone receptor function. Endocrinology 2001;142(1):319-331

2 Manna PR, Tena-Sempere M, Huhtaniemi IT. Molecular mechanisms of thyroid hormone-stimulated steroidogenesis in mouse leydig tumor cells. Involvement of the steroidogenic acute regulatory (StAR) protein. J Biol Chem 1999;274(9):5909-5918

3 Maran RR, Arunakaran J, Aruldhas MM. T3 directly stimulates basal and modulates LH induced testosterone and oestradiol production by rat Leydig cells in vitro. Endocr J 2000;47(4):417-428
4 Kumar A, Mohanty BP, Rani L. Secretion of testicular steroids and gonadotrophins in hypothyroidism. Andrologia 2007;39(6):253-260

5 Teerds KJ, de Rooij DG, de Jong FH, van Haaster LH. Development of the adult-type Leydig cell population in the rat is affected by neonatal thyroid hormone levels. Biol Reprod 1998;59(2):344-350

6 Hardy MP, Sharma RS, Arambepola NK, et al. Increased proliferation of Leydig cells induced by neonatal hypothyroidism in the rat. J Androl 1996;17(3):231-238

7 Cristovão FC, Bisi H, Mendonça BB, Bianco AC, Bloise W. Severe and mild neonatal hypothyroidism mediate opposite effects on Leydig cells of rats. Thyroid 2002;12(1):13-18

8 Rao JN, Liang JY, Chakraborti P, Feng P. Effect of thyroid hormone on the development and gene expression of hormone receptors in rat testes in vivo. J Endocrinol Invest 2003;26(5):435-443

9 Kumar A, Chaturvedi PK, Mohanty BP. Hypoandrogenaemia is associated with subclinical hypothyroidism in men. Int J Androl 2007;30(1):14-20

10 Mendis-Handagama SM, Siril Ariyaratne HB. Leydig cells, thyroid hormones and steroidogenesis. Indian J Exp Biol 2005;43(11):939-962

11 Rebois RV. Establishment of gonadotropin-responsive murine leydig tumor cell line. J Cell Biol 1982;94(1):70-76

12 Cascio C, Prasad VV, Lin YY, Lieberman S, Papadopoulos V. Detection of P450c17-independent pathways for dehydroepiandrosterone (DHEA) biosynthesis in brain glial tumor cells. Proc Natl Acad Sci U S A 1998;95(6):2862-2867

13 O'Shaughnessy PJ, Morris ID, Baker PJ. Leydig cell re-generation and expression of cell signaling molecules in the germ cell-free testis. Reproduction 2008;135(6):851-858

14 Marians RC, Ng L, Blair HC, Unger P, Graves PN, Davies TF. Defining thyrotropin-dependent and -independent steps of thyroid hormone synthesis by using thyrotropin receptor-null mice. Proc Natl Acad Sci U S A 2002;99(24):15776-15781

15 Konieczna A, Szczepańska A, Sawiuk K, Węgrzyn G, Łyżeń $R$. Effects of partial silencing of genes coding for enzymes involved in glycolysis and tricarboxylic acid cycle on the enterance of human fibroblasts to the S phase. BMC Cell Biol 2015;16:16

16 Mehendale RG, Bruot BC. Thyroid stimulating hormone inhibits rat granulosa cell steroidogenesis in primary culture. Endocrine 1995;3(3):215-220

17 Agard JA, Duffy DM, Jacot T, Archer DF. Thyroid stimulating hormone (TSH) receptor on granulosa cells. Fertil Steril 2011;96(3):S118

18 Clark BJ, Wells J, King SR, Stocco DM. The purification, cloning, and expression of a novel luteinizing hormone-induced mitochondrial protein in MA-10 mouse Leydig tumor cells. Characterization of the steroidogenic acute regulatory protein (StAR) J Biol Chem 1994;269(45):28314-28322

19 Meinsohn MC, Smith OE, Bertolin K, Murphy BD. The orphan nuclear receptors steroidogenic factor-1 and liver receptor homolog-1: structure, regulation, and essential roles in mammalian reproduction. Physiol Rev 2019;99(2):1249-1279

20 Zirkin BR, Papadopoulos V. Leydig cells: formation, function, and regulation. Biol Reprod 2018;99(1):101-111

21 Hu J, Zhang Z, Shen WJ, Azhar S. Cellular cholesterol delivery, intracellular processing and utilization for biosynthesis of steroid hormones. Nutr Metab (Lond) 2010;7:47

22 Acconcia F, Marino M, Steroid hormones: synthesis, secretion, and transport. In: Belfiore A, LeRoith D, eds. Principles of Endocrinology and Hormone Action. Cham: Springer International Publishing; 2016: 1-31

23 Hall PF, Testicular steroid synthesis: organization and regulation. In: Knobil E, Neill J, eds. The Physiology of Reproduction. 2nd ed. New York, NY: Raven Press; 1994 1335-1362 
24 Payne AH, Abbaszade IG, Clarke TR, Bain PA, Park CH. The multiple murine 3 beta-hydroxysteroid dehydrogenase isoforms: structure, function, and tissue- and developmentally specific expression. Steroids 1997;62(1):169-175

25 Fadlalla MB, Wei Q, Fedail JS, Mehfooz A, Mao D, Shi F. Effects of hyper- and hypothyroidism on the development and proliferation of testicular cells in prepubertal rats. Anim Sci J 2017;88(12):1943-1954

26 Shekhar SDB, Gupta S, Kumar A. A unique anti-gonadotropic effect of TSH on Leydig cell derived Mltc-1 Line.The Endocrine Society Meeting. Available at: https://endo.confex.com/ endo/2017endo/meetingapp.cgi/Paper/31402. Accessed April 3, 2017

27 Sun SC, Hsu PJ, Wu FJ, Li SH, Lu CH, Luo CW. Thyrostimulin, but not thyroid-stimulating hormone (TSH), acts as a paracrine regulator to activate the TSH receptor in mammalian ovary. J Biol Chem 2010;285(6):3758-3765
28 Allgeier A, Offermanns S, Van Sande J, Spicher K, Schultz G, DumontJE.Thehumanthyrotropinreceptoractivates G-proteins Gs and Gq/11. J Biol Chem 1994;269(19):13733-13735

29 Krude $\mathrm{H}$, Biebermann $\mathrm{H}$, The thyroid and its regulation by the TSHR: evolution, development, and congenital defects. In: Luster M, Duntas LH, Wartofsky L, eds. The Thyroid and Its Diseases: A Comprehensive Guide for the Clinician. Cham: Springer International Publishing; 2019: 219-233

30 Reyland ME. Protein kinase $\mathrm{C}$ is a tonic negative regulator of steroidogenesis and steroid hydroxylase gene expression in Y1 adrenal cells and functions independently of protein kinase A. Mol Endocrinol 1993;7(8):1021-1030

31 LeHoux JG, Dupuis G, Lefebvre A. Control of CYP11B2 gene expression through differential regulation of its promoter by atypical and conventional protein kinase $\mathrm{C}$ isoforms. J Biol Chem 2001;276(11):8021-8028 